\title{
SYNTHESIS AND STUDY OF COMPLEXES OF COPPER(II), ZINC, COBALT(II) AND NICKEL(II) WITH NITROFLUORENYLIDENE-9-AMINO(IMINO) DERIVATIVES
}

\author{
S.B. Strashnova ${ }^{*}$, M.N. Zhuk, O.V.Kovalchukova, \\ P.V. Strashnov, B.E. Zaitsev \\ Peoples' Friendship University of Russia, Mikluho-Maklaya str. 5, 117198, Moscow, Russia \\ sstrashnova@mail.ru, Phone:+7(495)9550884,Fax:+7(495)9522164
}

\begin{abstract}
The complexes of general formula $\mathrm{MCl}_{2} \cdot \mathrm{L}^{1-4} \cdot \mathrm{nH}_{2} \mathrm{O}$ (where $\mathrm{L}^{1}$ - N-(2,4,7-trinitrofluorenilidene-9)$p$-dimethyl-aminoanilin, $\mathrm{L}^{2}$ - $N$-(2,4,5,7-tetranitrofluorenilidene-9)-p-dimethylaminoaniline, $\mathrm{L}^{3}-\quad N$-(2,4,7trinitrofluorenilidene)-N-(p-dimethylaminophenyl)hydroxylamine, $\mathrm{L}^{4}-\mathrm{N}$-(2,4,5,7-tetranitrofluorenilidene9)- $N$-( $p$-dimethylaminophenyl)-hydroxylamine; $\mathrm{M}=\mathrm{Cu}, \mathrm{Co}, \mathrm{Ni}, \mathrm{Zn} ; n=1-3$ have been synthesized and investigated by different methods. Spectral criteria of co-ordination of the molecules $\mathrm{L}^{1}-\mathrm{L}^{4}$ in electronic absorption spectra were detected. In experimental spectra, the high-frequency band disappears, so the co-ordination occurs through a lone electron pair of a $\mathrm{N}$-atom of the amino-group, and the ligand exists in a molecular form. A constant of acidic dissociation of $\mathrm{L}^{3}$ is determined spectrophotometrically: $\mathrm{pKa}=2,07$. Geometric optimization of $\mathrm{L}^{1}-\mathrm{L}^{4}$ was performed, and the effect of monoprotonation on the electron density was assessed quantum chemically. It was shown that the strongest change of the electron density while protonation occurs at the tertiary amine nitrogen.
\end{abstract}

Keywords: $3 d$ metals; complexes; nitrofluoreniliden-9-anilin; amino-group.

\section{Introduction}

Among derivatives of polynitrofluorenes, particularly 9-amino-derivatives and 9-hydrazine-derivatives, there are substances which possess anti-tumor activity [1]; or can be used as sensitizers in electrophotography or other fields of technique. Metallocomplexes of nitrofluorenilidene-9-hydroxylamino(imino) derivatives are not studied. Nitrofluorenilidene-9-hydroxylamino(imino)derivatives $\mathrm{L}^{1-4}$, were synthesized by condensation of tris- and tetranitrofluorenes with p-nitrozodimethylaniline in solutions of DMF [2]. Two products in approximately equal molar ratio are obtained: $\mathrm{N}$-(nitrofluorenilidene-9-)- $p$-dimethylaminoaniline and $\mathrm{N}$-(nitrofluorenilidene-9-)- $\mathrm{N}$-( $p$-dimethylaminophenyl) hydroxylamine. The mixture of the products was separated with the use of chromatography. Mostly possible, $\mathrm{L}^{3}$ and $\mathrm{L}^{4}$ are intermediate products of condensation. The structures of $\mathrm{L}^{1-4}$ were proved via mass spectroscopy and ${ }^{1} \mathrm{H}$ NMR spectroscopy.
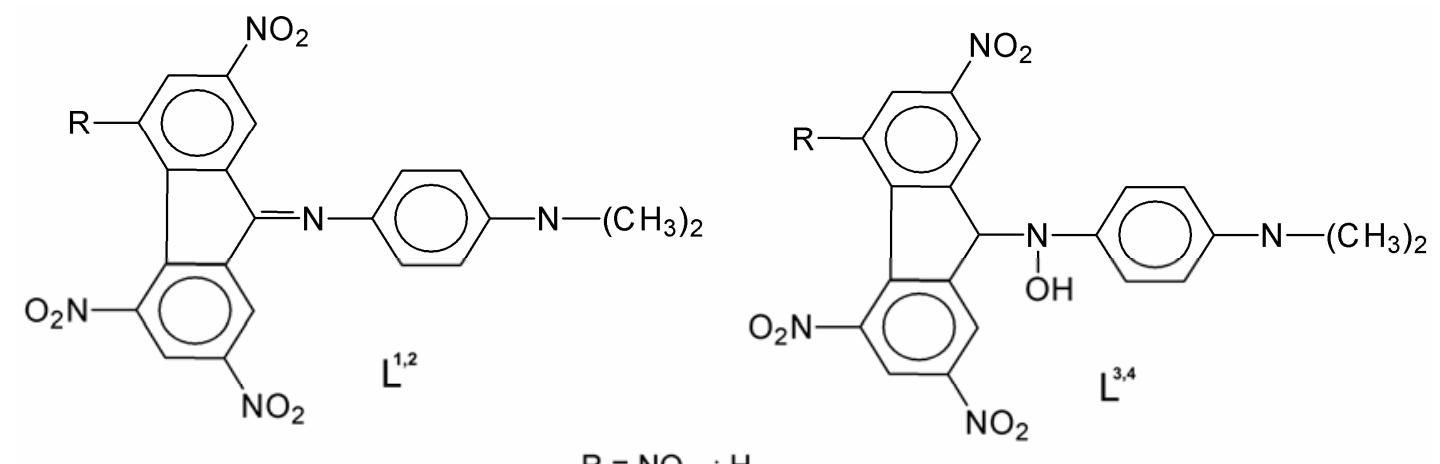

$$
\mathrm{R}=\mathrm{NO}_{2} ; \mathrm{H}
$$

Following on from our earlier work in the field of coordination compounds of nitrofluorene derivatives [3-5] in this paper we discuss our results of the study of new metallocomplexes with $\mathrm{L}^{1}-\mathrm{L}^{4}$, as far as investigation of their structures and physico-chemical properties.

\section{Results and discussion}

The investigated amino(imino)derivatives of polynitrofluorene have several potential centers of co-ordination. They may co-ordinate in molecular as well as in ionic forms through nitro- or imino- (or oximate) groups, the presented organic molecules contain a tertiary amino-group which potentially makes the choice of a center of co-ordination more difficult. In order to determine the most probable way of co-ordination of $\mathrm{L}^{1}-\mathrm{L}^{4}$, their geometrical optimization was performed (fig.1), the changes of electron density at mono-protonation were valued. According to 
calculations of the models, the strongest change of the electron density while protonation occurs at the tertiary amine nitrogens. Considering protonation as a kind of an analogue of co-ordination, one can propose the $\mathrm{N}$-atom of a diethylamino-group to be the most active co-ordination center of $\mathrm{L}^{1}-\mathrm{L}^{4}$.

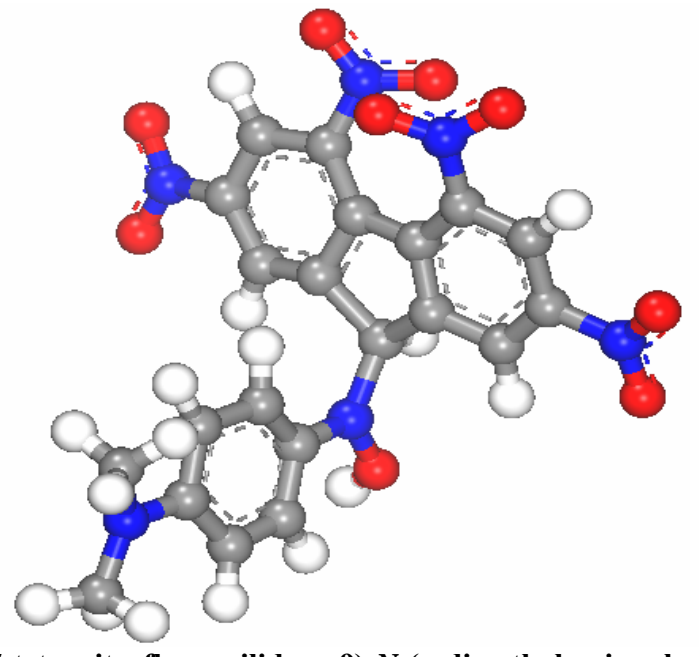

Fig.1. Spatial structure of $N$-(2,4,5,7-tetranitrofluorenilidene-9)- $N$-(p-dimethylaminophenyl)-hydroxylamine $\left(\mathrm{L}^{4}\right)$

Spectral investigations of non coordinated ligands and their complexes were performed. IR spectra of $\mathrm{L}^{1}-\mathrm{L}^{4}$ have characteristic bands in the range of stretching modes of nitro-groups: $v^{\text {as }}\left(\mathrm{NO}_{2}\right)=1535-1542 \mathrm{~cm}^{-1}$ and $v^{\mathrm{s}}\left(\mathrm{NO}_{2}\right)=1349-1355 \mathrm{~cm}^{-1}[6]$. The absorption bands practically do not change while co-ordination. IR spectra of $\mathrm{L}^{1}$ and $\mathrm{L}^{2}$ are characterized by intensive absorption band at $1127-1138 \mathrm{~cm}^{-1}$, which is related to stretching modes of $\mathrm{C}-\mathrm{N}$ bonds of aromatic amines, as far as at $1614-1616 \mathrm{~cm}^{-1}$ which can be related to $\mathrm{C}=\mathrm{C}$ and $\mathrm{C}=\mathrm{N}$ stretches. In the spectra of complexes (I-IV) these bands shift to $1738 \mathrm{~cm}^{-1}$ and sharp bands appear in the area 3445,3344 and $3090 \mathrm{~cm}^{-1} . \mathrm{L}^{3}$ and $\mathrm{L}^{4}$ are phenylhydroxylamines. Their IR spectra are characterized by wide bands of $v(\mathrm{OH})=3420-3460 \mathrm{~cm}^{-1}$. Strong widening of the band can be explained by strong inter-molecular hydrogen bonds.

In electronic absorption spectra of non-coordinated ligands were registered bands at $27933 \mathrm{~cm}^{-1}$ and $14493 \mathrm{~cm}^{-}$ ${ }^{1}$ for $\mathrm{L}^{1}$ as well as at $27778 \mathrm{~cm}^{-1}$ and $14578 \mathrm{~cm}^{-1}$ for $\mathrm{L}^{2}$. While deprotonation a series of isobestic points at $38537 \mathrm{~cm}^{-}$ $1,36585 \mathrm{~cm}^{-1}, 33333 \mathrm{~cm}^{-1}$ and $29675 \mathrm{~cm}^{-1}$ appear. This indicates the equilibrium of neutral and cationic forms of ligands in solution. As it was shown already in [7], in case of co-ordination through an N-atom of an amino-group, a high-frequency band of $\pi \mathrm{l}-\pi^{*}$ transition with $v_{\max }=15122 \mathrm{~cm}^{-1}$ should disappear as well as in case of co-ordination through a lone electron pair of an imino-group, the maximum of this band should undergo a batochrome shift. Spectrophotometrical titration of solutions of ligands $\mathrm{L}^{1}-\mathrm{L}^{2}$ with salts of d-metals leads to disappearance of the highfrequency band (fig. 2). It indicates that the co-ordination occurs through a lone electron pair of a $\mathrm{N}$-atom of the amino-group, and the ligand exists in a molecular form. A constant of acidic dissociation of $\mathrm{L}^{1}$ is determined spectrophotometrically: $\mathrm{pKa}=2,07$.

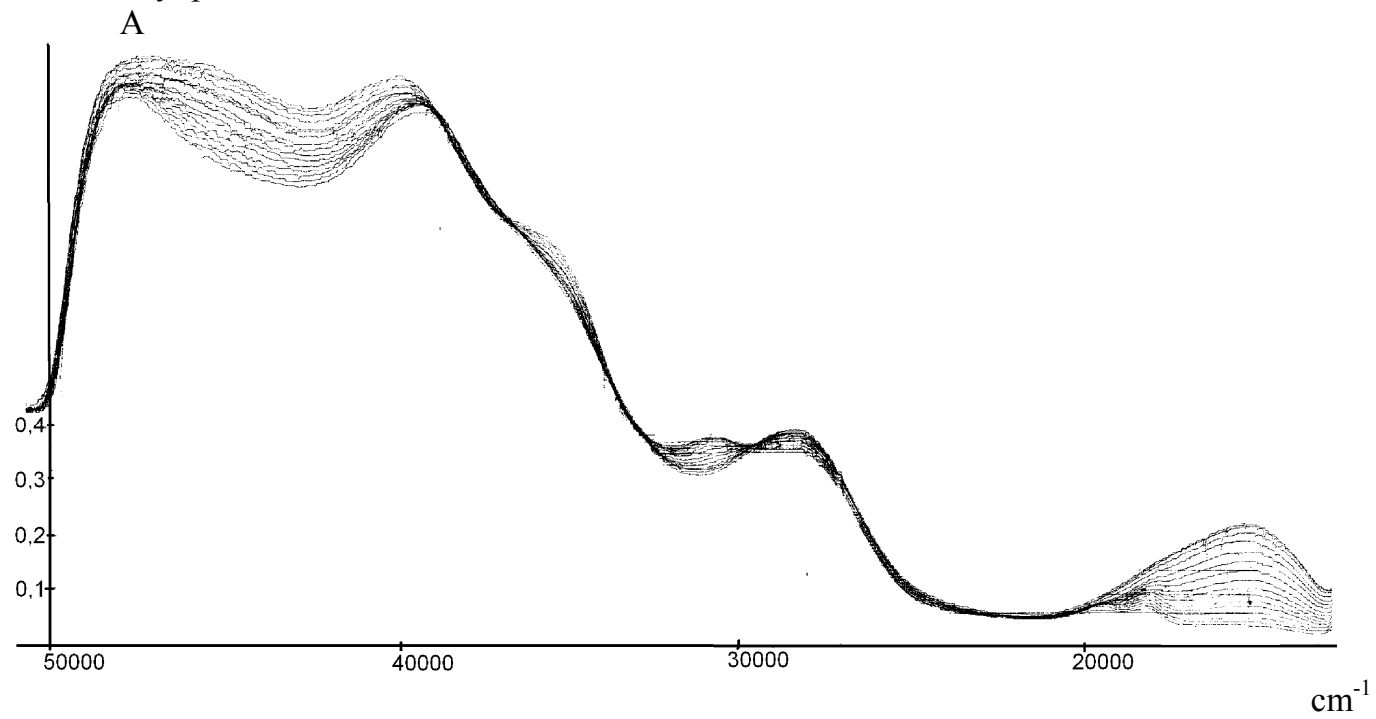

Fig. 2. Spectrophotometrical titration of solution of ligand $\mathrm{L}^{1}$ with $\mathrm{CuCl}_{2}$ solution.

Electronic absorption spectra of non co-ordinated $\mathrm{L}^{3}$ and $\mathrm{L}^{4}$ are characterized by a short-frequency band with a maximum at $27930 \mathrm{~cm}^{-1}$ and a band at $14490 \mathrm{~cm}^{-1}$ which points the input of the electronic density of amine nitrogen. 
Both protonation and complex formation lead to disappearance of absorption at $14490 \mathrm{~cm}^{-1}$. This proves the coordination of ligands through the amine nitrogen. The character of changes of electronic spectra of $\mathrm{L}^{3}$ and $\mathrm{L}^{4}$ in ethanol and $\mathrm{CCl}_{4}$ solution with the rise of $\mathrm{pH}$ indicates the process of their alkaline dehydration as the spectra become identical to those of $\mathrm{L}^{1}$ and $\mathrm{L}^{2}$. While complexing in neutral and slightly acidic media, the coordination of $\mathrm{L}^{3}$ and $\mathrm{L}^{4}$, as far as of $\mathrm{L}^{1}$ and $\mathrm{L}^{2}$ takes place through an $\mathrm{N}$-atom of an amino-group.

According to the elemental analysis results metal cation - ligand ratio is 1:1. The presence of two chlorine atoms in complexes (I-VII) proves the neutral form of $\mathrm{L}^{1}-\mathrm{L}^{4}$ in complexes. There are up to three water molecules per complex. In order to determine if the character of water molecules binding is complex or cristallizational, thermostability of the complexes was assessed thermogravimetrically in the range of temperatures from 20 to $800{ }^{\circ} \mathrm{C}$ degrees. It is shown that mass starts to decrease at $120-150{ }^{\circ} \mathrm{C}$. The magnitude of this decrease corresponds to the separation of one or two water molecules. So, all of the complexes have one or two water molecules of cristallizational nature whereas complex (III) probably contains one molecule of coordinated water (Table 1)

\section{Experimental}

General. The carbon and hydrogen content was determined by standard micro-methods in the microanalytical group. The metals(II) was determined by trilonometric method using the murexid as indicator [8].

IR spectra of non coordinated ligands and synthesized complexes of polycrystalline samples were recorded using Specord 75-IR in frequency range $4000-400 \mathrm{~cm}^{-1}$. UV-visible spectra at different $\mathrm{pH}$ values of the ligands and their coordinate compounds were registered on a spectrophotometer Specord UV-VIS in the interval $50000-15000 \mathrm{~cm}^{-1}$.

Geometric optimization of the molecules was performed using the FireFly/PC GAMESS program at the DFT-B3LYP level [9].

Synthesis. $10^{-3}$ moles of $\mathrm{L}^{3}-\mathrm{L}^{6}$ were dissolved in $25 \mathrm{ml}$ of hot DMF $\left(60-65^{\circ} \mathrm{C}\right)$, and a hot ethanol solution of a corresponding metal salt was added dropwise while intensive stirring. After all the ligand underwent the reaction (chromatographic control) the reaction mixture was immediately cooled and left until the crystallization of complexes started. The obtained compounds were filtrated, washed with ethanol and dried in dessicator over $\mathrm{P}_{2} \mathrm{O}_{5}$ up to a constant mass. $\mathrm{CuCl}_{2} \cdot L^{1} \cdot 2 \mathrm{H}_{2} \mathrm{O}$ (I) Found, \% C, 41.12; H, 3.18; N, 11.84; Cl, 11.50; Cu, 10.81. Calc. for $\mathrm{C}_{21} \mathrm{H}_{19} \mathrm{~N}_{6} \mathrm{O}_{7} \mathrm{Cl}_{2} \mathrm{Cu}, \mathrm{M}=603.5$ $\mathrm{g} \mathrm{mole}^{-1} \%$ : C, 41.76; H, 3.15; N, 11.60; Cl, 11.76; Cu, 10.52. The yield was $61 \%$. IR spectrum (nujol oil, $\mathrm{cm}^{-1}$ ): $1138 \mathrm{~s}, 1355 \mathrm{~s}, 1538 \mathrm{~s}, 1616 \mathrm{~m}, 2908 \mathrm{~m}$,

$\mathrm{NiCl}_{2} \cdot \mathrm{L}^{1} \cdot \mathrm{H}_{2} \mathrm{O}$ (II) Found, \% C, 43.08; H, 3.02; N, 12.36; Cl, 12.08; Ni, 10.31. Calc. for $\mathrm{C}_{21} \mathrm{H}_{17} \mathrm{~N}_{6} \mathrm{O}_{6} \mathrm{Cl}_{2} \mathrm{Cu}, \mathrm{M}_{-1}=581 \mathrm{~g}$ mole $^{-1} \%$ : C, 43.37; H, 2.93; N, 12.05; Cl, 12.22; Ni, 10.10. The yield was 56\%. IR spectrum (nujol oil, $\mathrm{cm}^{-1}$ ): $1134 \mathrm{~s}$, $1351 \mathrm{~s}, 1535 \mathrm{~s}, 1614 \mathrm{~m}, 2912 \mathrm{~m}$,

$\mathrm{CuCl}_{2} \cdot \mathrm{L}^{2} \cdot 3 \mathrm{H}_{2} \mathrm{O}$ (III) Found, \% C, 37.12; H, 2.89; N, 14.68; Cl, 10.40; Cu, 9.46. Calc. for $\mathrm{C}_{21} \mathrm{H}_{20} \mathrm{~N}_{7} \mathrm{O}_{11} \mathrm{Cl}_{2} \mathrm{Cu}, \mathrm{M}$ $680.5 \mathrm{~g} \mathrm{~mole}^{-1} \%$ : C, 37.03; H, 2.94; N, 14.40; Cl, 10.43; Cu, 9.33. The yield was 65\%. IR spectrum (nujol oil, $\mathrm{cm}^{-1}$ ): $1130 \mathrm{~s}, 1348 \mathrm{~s}, 1538 \mathrm{~s}, 1618 \mathrm{~m}, 2916 \mathrm{~m}$,

$\mathrm{CoCl}_{2} \cdot \mathrm{L}^{2} \cdot 2 \mathrm{H}_{2} \mathrm{O}(\boldsymbol{I V})$ Found, \% C, 38.90; H, 2.81; N, 13.16; Cl, 11.11; Co, 8.98. Calc. for $\mathrm{C}_{21} \mathrm{H}_{18} \mathrm{~N}_{7} \mathrm{O}_{10} \mathrm{Cl}_{2} \mathrm{Co}, \mathrm{M}=644 \mathrm{~g}$ mole $^{-1} \%$ : C, 39.13; H, 2.79; N, 13.04; Cl, 11.02; Co, 9.16. The yield was 48\%. IR spectrum (nujol oil, $\mathrm{cm}^{-1}$ ): $1128 \mathrm{~s}$, $1355 \mathrm{~s}, 1535 \mathrm{~s}, 1618 \mathrm{~m}, 2908 \mathrm{~m}$,

$\mathrm{CuCl}_{2} \cdot \mathrm{L}^{3} \cdot 2 \mathrm{H}_{2} \mathrm{O}(\boldsymbol{V})$ Found, \% C, 40.02; H, 3.22; N, 13.40; Cl, 11.20; Cu, 10.20. Calc. for $\mathrm{C}_{21} \mathrm{H}_{20} \mathrm{~N}_{6} \mathrm{O}_{9} \mathrm{Cl}_{2} \mathrm{Cu}, \mathrm{M}_{-1}=634.5$ g mole $^{-1} \%$ : C, 39.75; H, 3.15; N, 13.25; Cl, 11.20; Cu, 10.02. The yield was $61 \%$. IR spectrum (nujol oil, $\mathrm{cm}^{-1}$ ): $950 \mathrm{~s}$, $1127 \mathrm{~m}, 1340 \mathrm{~s}, 1538 \mathrm{~s}, 2898 \mathrm{~m}, 3426 \mathrm{~m}$,

$\mathrm{CuCl}_{2} \cdot \mathrm{L}^{4} \cdot 2 \mathrm{H}_{2} \mathrm{O}$ (VI) Found, \% C, 37.42; H, 3.08; N, 14.40; Cl, 10.40; Cu, 9.20. Calc. for $\mathrm{C}_{21} \mathrm{H}_{19} \mathrm{~N}_{7} \mathrm{O}_{11} \mathrm{Cl}_{2} \mathrm{Cu}, \mathrm{M}=679.5$ $\mathrm{g} \mathrm{mole}^{-1} \%$ : C, 37.22; H, 3.15; N, 14.41; Cl, 10.44; Cu, 9.34. The yield was 50\%. IR spectrum (nujol oil, $\mathrm{cm}^{-1}$ ): $950 \mathrm{~s}$, $1126 \mathrm{~m}, 1344 \mathrm{~s}, 1542 \mathrm{~s}, 2910 \mathrm{~m}, 3432 \mathrm{~m}$,

$\mathrm{ZnCl}_{2} \cdot \mathrm{L}^{4} \cdot \mathrm{H}_{2} \mathrm{O}$ (VII) Found, \% C, 38.12; H, 2.60; N, 14.80; Cl, 11.95; Zn, 9.98. Calc. for $\mathrm{C}_{21} \mathrm{H}_{17} \mathrm{~N}_{7} \mathrm{O}_{10} \mathrm{Cl}_{2} \mathrm{Zn}, \mathrm{M}=663 \mathrm{~g}$ mole $^{-1} \%$ : C, 38.00; H, 2.56; N, 14.78; Cl, 11.71; Zn, 9.80. The yield was 43\%. IR spectrum (nujol oil, $\mathrm{cm}^{-1}$ ): $958 \mathrm{~s}$, $1128 \mathrm{~m}, 1354 \mathrm{~s}, 1542 \mathrm{~s}, 2902 \mathrm{~m}, 3460 \mathrm{~m}$.

Table 1. Results of the thermogravimetric analysis

\begin{tabular}{|l|l|l|l|l|l|}
\hline \multicolumn{1}{|c|}{ compound } & \multicolumn{1}{c|}{$\begin{array}{c}\mathrm{m} \text { (of weighed part), } \\
\mathrm{mg}\end{array}$} & \multicolumn{1}{c|}{$\begin{array}{c}-\Delta \mathrm{m}\left(150^{\circ}\right), \\
\mathrm{mg}\end{array}$} & $\begin{array}{c}\mathrm{H}_{2} \mathrm{O} \text { cryst., } \\
\%\end{array}$ & $\begin{array}{c}-\Delta \mathrm{m} \\
\left(800^{\circ}\right) \mathrm{mg}\end{array}$ & $\begin{array}{c}\mathrm{m}(\mathrm{rest}) \\
\left(\mathrm{M}_{\mathrm{x}} \mathrm{O}_{\mathrm{y}}\right), \mathrm{mg}^{\mathrm{mg}}\end{array}$ \\
\hline I & 127.2 & 7.43 & 5.84 & 102.97 & 16.80 \\
\hline II & 170.0 & 5.27 & 3.00 & 137.43 & 27.30 \\
\hline III & 132.2 & 7.00 & 5.30 & 105.6 & 19.60 \\
\hline IV & 144.8 & 8.10 & 5.50 & 115.5 & 21.20 \\
\hline V & 178.5 & 10.14 & 5.68 & 145.86 & 22.50 \\
\hline VI & 164.0 & 8.60 & 5.24 & 136.4 & 19.00 \\
\hline VII & 148.0 & 3.73 & 2.52 & 126.47 & 17.80 \\
\hline
\end{tabular}




\section{Conclusions}

The interaction of new ligands $N$-(nitrofluorenilidene-9)-p-dimethylaminoanilines $\left(\mathrm{L}^{1}, \mathrm{~L}^{2}\right)$, and $N$-(nitrofluorenilidene-9)- $N$-(p-dimethyl-aminophenyl)hydroxylamine $\left(\mathrm{L}^{3}, \mathrm{~L}^{4}\right)$ with the metal salts $\left(\mathrm{CuCl}_{2}, \mathrm{ZnCl}_{2}, \mathrm{CoCl}_{2}\right.$ and $\mathrm{NiCl}_{2}$ results the compound of general formula $\mathrm{MCl}_{2} \cdot \mathrm{L}^{1-4} \cdot n \mathrm{H}_{2} \mathrm{O}$. The co-ordination of ligands occurs through a lone electron pair of a $\mathrm{N}$-atom of the amino-group in the 1 to 1 mole ratio $1: 1$, and the ligand exists in a molecular neutral form. A constant of acidic dissociation of $\mathrm{L}^{3}$ is determined spectrophotometrically: $\mathrm{pKa}=2,07$.

\section{Acknowledgments}

The research described in this publication was made possible in part by the financial support of the RFBR project $\mathrm{n}^{\circ}$ 07-03-00020-a.

\section{References}

[1] Degutis J.A., Kurtinaitis J.I. Chemical therahy of tumor. Moskva: 1982, 36, 240p. (rus).

[2] Organicum (trans. Potapov V.M. Moskva: Mir. -1979, V.2, 434p. (rus).

[3] Zaitsev B.E., Strashnova S. B., Riabov M.A., J. Inorg Chem. 1996, 41, 1142-1145 (rus).

[4] Minacheva L. Kh., Sergienko V. S., Strashnova S. B. et all, Kristallografiya. 2005, 50, 79-83 (rus).

[5] Strashnova S. B., Avramenko O.V., Sergienko V. S. et all, J. inorg chem. 2008, 53, 1697-1702 (rus).

[6] Nakamoto K. Infrakrasnye spectry I spectry KR neorganiceskih I organiceskih soedinenii. Moskva: Mir. 1991, 540p. (rus).

[7] Zaytsev B.E. Spectral coordination chemistry. Moskva: Rudn.-1991, 272p. (rus).

[8] Schwarzenbach G., Flaschka H. Kompleksonometriceskoe titrovanie. Publ. "Himia", Moskva, 1970, 359p. (rus.)

[9] Alex A. Granovsky, PC GAMESS/Firefly version 7.1.F, 